\title{
Aged black garlic extract induces inhibition of gastric cancer cell growth in vitro and in vivo
}

\author{
XIN WANG $^{1,2^{*}}$, FEI JIAO ${ }^{3 *}$, QIN-WEN WANG ${ }^{1}$, JUAN WANG $^{4}$, KE YANG $^{1}$, \\ RONG-RONG HU ${ }^{1}$, HAN-CHEN LIU ${ }^{1}$, HONG-YANG WANG ${ }^{2}$ and YI-SHAN WANG ${ }^{1}$ \\ ${ }^{1}$ The Center of Non-Traumatic Treatment and Diagnosis of Tumor, Binzhou Medical College Affiliated \\ The PLA 107 Hospital, Yantai, Shandong 264002; ${ }^{2}$ Laboratory on Signal Transduction, Eastern Hepatobiliary \\ Surgery Institute, Second Military Medical University, Shanghai 200438; ${ }^{3}$ Department of Biochemistry \\ and Molecular Biology, Binzhou Medical College, Yantai, Shandong 264003; ${ }^{4}$ Department of \\ Biotechnology, Binzhou Medical College, Yantai, Shandong 264003, P.R. China
}

Received May 26, 2011; Accepted September 5, 2011

DOI: $10.3892 / \mathrm{mmr} .2011 .588$

\begin{abstract}
There is mounting evidence that garlic extracts possess significant anticancer actions. However, no studies have been reported on the effects of aged black garlic extracts (ABGE) on gastric cancer in vitro or in vivo. To examine the potential action of ABGE against gastric cancer, the present study evaluated its effect on the inhibition of cell proliferation and induction of apoptosis in SGC-7901 human gastric cancer cells. Additionally, we performed an in vivo study by inoculating the murine foregastric carcinoma cell line in Kunming mice and treating them with various doses of $\operatorname{ABGE}(0,200$, 400 and $800 \mathrm{mg} / \mathrm{kg}$, intraperitoneally) for 2 weeks. Dosedependent apoptosis was detected in ABGE-treated cells in in vitro studies. In tumor-bearing mice, significant antitumor effects of ABGE were observed, such as growth inhibition of inoculated tumors. Further investigation of serum superoxide dismutases, glutathione peroxidase, interleukin-2 and the increased indices of spleen and thymus indicated that the anticancer action of ABGE may be partly due to its antioxidant and immunomodulative effects.
\end{abstract}

\section{Introduction}

Gastric cancer is the fourth most common cancer worldwide, with 700,000 confirmed deaths annually (1). Epidemiological

Correspondence to: Dr Yi-Shan Wang, The Center of Non-Traumatic Treatment and Diagnosis of Tumor, Binzhou Medical College Affiliated The PLA 107 Hospital, No. 7 Southern Zhichu Road, Yantai, Shandong 264002, P.R. China

E-mail: wangyishan288@163.com

${ }^{*}$ Contributed equally

Key words: garlic, gastric cancer, apoptosis, antioxidant, immunity studies indicate that gastric cancer is associated with a low intake of fruits and vegetables (2). Surgery, chemotherapy, and radiotherapy are still the major conventional cancer therapies for this malignancy (3). However, these therapies have numerous limitations due to low response and poor outcome, indicating that there is an urgent need for the development of novel therapeutic strategies.

Garlic (Allium sativum) has been used for disease prevention and treatment for over 4,000 years. Numerous favorable biological and pharmacological effects of consumption of garlic preparations have been reported in culture cells in vitro and in animal models in vivo (4). Of the beneficial actions of garlic, such as antitumorigenesis, antiatherosclerosis, blood sugar modulation and antibiosis, inhibition of the growth of cancer is perhaps the most notable (5). Preclinical studies and population-based case control studies provide the most compelling evidence linking garlic and related foods with activity against cancer, confirming an inverse correlation between dietary intake of Allium vegetables and the risk of various cancer types (6).

Among the numerous garlic preparations available, aged black garlic extract (ABGE) is used as a major component of non-prescription tonics and dietary supplements (7). Compared to raw garlic, it has been shown to be more potent in many of the therapeutic properties of garlic, such as immunomodulative and antioxidative effects (8). In addition, ABGE, which is produced by a long-term extraction from garlic in aqueous ethanol, does not cause adverse events and has been confirmed to be safe in preclinical trials (9).

Although a number of epidemiological studies present promising evidence regarding the role of garlic in gastric cancer etiology, the pharmacological mechanism by which ABGE may inhibit gastric cancer remains unclear. In the present study, the immunomodulative and antioxidant effects of ABGE were investigated in SMG-7901 cells in vitro and in a transplantable mouse model in vivo to investigate its potential use as an anti-cancer agent for gastric cancer. To the best of our knowledge, this is the first study to explore the effect of ABGE in gastric cancer. 


\section{Materials and methods}

Preparation of aged black garlic extract. Aged black garlic was purchased from Huagu Garlic Co., Ltd. (Dalian, China). ABGE was prepared by the following steps: briefly, $100 \mathrm{~g}$ of peeled aged black garlic was crushed with $100 \mathrm{ml}$ of distilled water in a mortar. The crushed material was carefully decanted by pressing and $100 \mathrm{ml}$ of aqueous extract was collected and designated as $1 \mathrm{~g} / \mathrm{ml}$ of ABGE. The ABGE solution was kept at $-80^{\circ} \mathrm{C}$ before use.

Cell culture and treatment. SGC-7901 cells were obtained from the Shanghai Institute of Biochemistry and Cell Biology, Chinese Academy of Sciences (Shanghai, China) and cultured in Dulbecco's modified Eagle's medium containing $10 \%$ fetal bovine serum at $37^{\circ} \mathrm{C}$ in a humidified incubator supplemented with $5 \% \mathrm{CO}_{2}$.

The cell subgroups of the in vitro study were designed as follows: group A, SGC-7901 cells without treatment as a negative control; group B, SGC-7901 cells treated with a low dose of ABGE $(10 \mathrm{mg} / \mathrm{ml})$; group C, SGC-7901 cells treated with a middle dose of ABGE (50 mg/ml); group D, SGC-7901 cells treated with a high dose of ABGE $(100 \mathrm{mg} / \mathrm{ml})$; group E, SGC-7901 cells treated with cisplatin $(20 \mu \mathrm{g} / \mathrm{ml})$ as a positive control. SGC-7901 cells were seeded at a density of $5 \times 10^{4}$ cells per well in 6-well plates and incubated for $24 \mathrm{~h}$. ABGE was added to the culture media at various concentrations in the $0-100 \mathrm{mg} / \mathrm{ml}$ range, and the cells were then incubated for $48 \mathrm{~h}$. All cells were plated in culture medium containing serum into 6-well plates at the same time. Each concentration was examined in duplicate, whereas the whole experiment was performed 3 times. After $48 \mathrm{~h}$, the cells in the 5 groups were collected, washed twice with PBS, and fixed in $70 \%$ ethanol overnight at $-20^{\circ} \mathrm{C}$. The ethanol was then removed by centrifugation. Cell density was adjusted to $5 \times 10^{5}$ cell $/ \mathrm{ml}$ with PBS buffer, and $500 \mu \mathrm{l}$ of mixed staining solution was added to the cells for $30 \mathrm{~min}$ in the dark. Cells were analyzed by flow cytometry for detection of apoptosis. The mixed staining solution contained $0.125 \mathrm{~g}$ sodium citrate, $0.75 \mathrm{ml}$ Triton X-100, $0.03 \mathrm{~g}$ propidium iodide $(\mathrm{PI})$, and $0.01 \mathrm{~g}$ RNase in a final volume of $250 \mathrm{ml}$ (Sigma, St. Louis, MO, USA).

Animal experimentation. Male white mice of the Kunming strain, were acquired from the Laboratory Animal Center of Shandong Luye Biology Co. Ltd. [License No. (Lu): SCXK No. 021501], weighing $20 \pm 2 \mathrm{~g}$. The animals were housed in an environmentally controlled room at $21-22^{\circ} \mathrm{C}$ with a 12-h light/dark cycle 08:00-20:00. All procedures involving animals were approved by the institutional Animal Care and Use Committee and followed the guidelines set by the Medicine Animal Research Policies Committee of Shandong Province.

The mice were randomly divided into 5 groups and received different treatments. Briefly, mice of different groups were subcutaneously inoculated with $8 \times 10^{5}$ murine forestomach cells (MFC) under the right axilla. The tumor-bearing mice models were successfully established 1 week after inoculation and the experimental animal groups were set up as follows: group A, tumor-bearing control mice with daily intraperitoneal (i.p.) injection of $100 \mathrm{mg} / \mathrm{kg}$ saline water as a negative control; group B, tumor-bearing mice injected with $200 \mathrm{mg} / \mathrm{kg}$ (low dose) ABGE; group $\mathrm{C}$, tumor-bearing mice injected with $400 \mathrm{mg} / \mathrm{kg}$ (medium dose) ABGE; group D, tumor-bearing mice injected with $800 \mathrm{mg} / \mathrm{kg}$ (high dose) ABGE; and group E, tumor-bearing mice injected with $60 \mathrm{mg} / \mathrm{kg}$ cyclophosphamide (CTX) as a positive control. The number of animals in each group at the beginning of the experiment was 12. ABGE was administered to the assigned groups at 17:00 every day for 2 weeks via i.p. injection, after which the tumor tissues were excised and weighed. During the experiment, the long and short diameters of the tumors were measured at specified time points (days 1, 4, 7, 11 and 14), and the tumor volume (V) was calculated using the following formula: $V=4 / 39 \pi$ $\mathrm{x} \mathrm{L} / 2 \mathrm{x}(\mathrm{W} / 2)^{2}$, where $\mathrm{L}$ and $\mathrm{W}$ are the long and short axes, respectively (10). Mice were sacrificed by cervical dislocation on day 14. Spleen, thymus and tumor tissues were removed and weighed. The index of the spleen (or thymus) was calculated from the formula: Spleen (or thymus) index = weight of spleen (or thymus)/ body weight x $100 \%$. The inhibition rate of tumor growth=(average tumor weight of the control group average tumor weight of the test group)/average tumor weight of the control group x $100 \%$ (11). Meanwhile, the whole blood from each animal was collected in a 14-ml Falcon tube. The remaining blood was centrifuged at $1,600 \mathrm{~g}$ for $15 \mathrm{~min}$, and separated serum was preserved at $-80^{\circ} \mathrm{C}$ until further analysis.

Activity detection of serum superoxide dismutase (SOD) and glutathione peroxidase (GSH-Px) in tumor-bearing mice. SOD activity was determined with the xanthine oxidasecytochrome c method according to a previous study (12). The cytochrome $\mathrm{c}$ reduction by superoxide anions generated by xanthine oxidase/hypoxanthine reaction was detected at $550 \mathrm{~nm}$. Activity values were expressed in U/ml; 1 unit of SOD was defined as the amount of sample producing $50 \%$ inhibition under the assay conditions.

Measurement of GSH-Px activity was based on the method described by Kaynar et al (13). The whole activity of GSH-Px was evaluated using the oxidation of glutathione (GSH) reacted with cumene hydroperoxide. In the presence of glutathione reductase and NADPH, the oxidized glutathione is immediately converted to the reduced form with a concomitant oxidation of NADPH to $\mathrm{NADP}^{+}$. The reduction in the absorbance of NADPH at $340 \mathrm{~nm}$ was measured. One unit of GSH-Px activity is defined as the amount of enzyme that catalyzes the oxidation of $1 \mu \mathrm{mol}$ of reduced glutathione (GSH) by cumene hydroperoxide to oxidized GSH per min at $\mathrm{pH} 7.0$ at $37^{\circ} \mathrm{C}$.

Concentration detection of serum interleukin-2 (IL-2) in tumor-bearing mice. The enzyme-linked immunosorbent assay (ELISA) was used to measure the levels of IL-2 from blood serum in treated mice as previously described (14). The serum samples $(50 \mu \mathrm{l})$ were added to each well of the reaction plate. The reaction plate was stored at $37^{\circ} \mathrm{C}$ for $1 \mathrm{~h}$, and was subsequently washed 4 times and blotted on filter paper. The enzyme-labeled antibody $(50 \mu \mathrm{l})$ was placed in each well and was stored at $37^{\circ} \mathrm{C}$ for $1.5 \mathrm{~h}$; the reaction plate was then washed as described above. The substrate $\mathrm{A}(50 \mu \mathrm{l})$ and $\mathrm{B}(50 \mu \mathrm{l})$ was placed into each well and allowed to react for $15 \mathrm{~min}$ in the dark at $37^{\circ} \mathrm{C}$. Lastly, one drop of stop buffer was added to each 
A

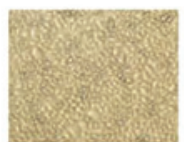

$\mathrm{NC}$

B

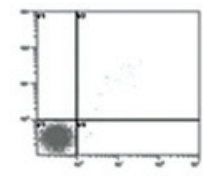

$\mathrm{NC}$

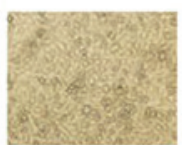

$10 \mathrm{mg} / \mathrm{ml}$

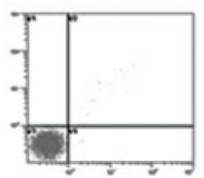

$10 \mathrm{mg} / \mathrm{ml}$

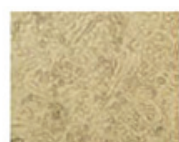

$50 \mathrm{mg} / \mathrm{ml}$

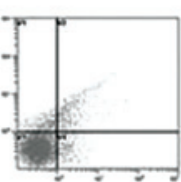

$50 \mathrm{mg} / \mathrm{ml}$

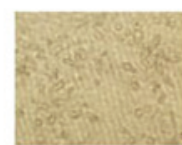

$100 \mathrm{mg} / \mathrm{ml}$

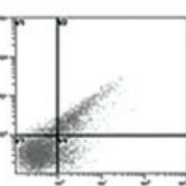

$100 \mathrm{mg} / \mathrm{ml}$

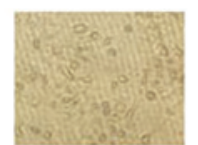

cisplatin

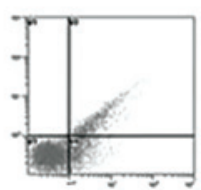

cisplatin

C

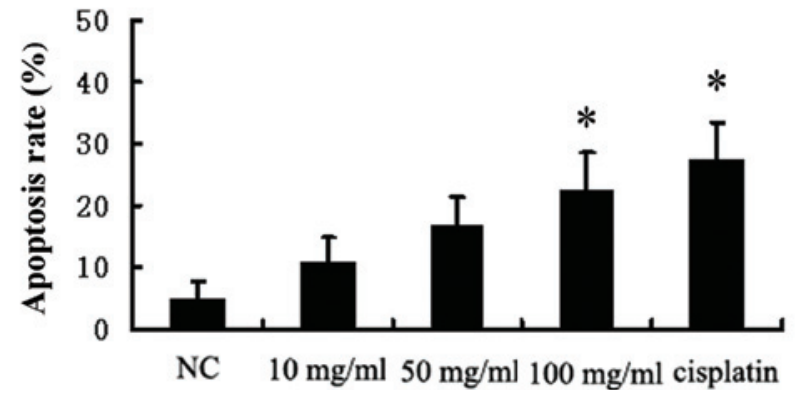

Figure 1. Effect of ABGE on the proliferation and apoptosis of SGC-7901 cells in vitro. SGC-7901 cells were treated with various concentrations of ABGE for $48 \mathrm{~h}$; SGC-7901 cells without treatment were used as a negative control and SGC-7901 cells treated with cisplatin ( $20 \mu \mathrm{g} / \mathrm{ml})$ as a positive control, repectively. The cells were then harvested, stained with PI, and analyzed by flow cytometry. (A) Morphological analysis of SGC-7901 cells treated with various concentrations of ABGE using phase-contrast microscopy. (B) Representative results of apoptosis assessment by Annexin-V/PI double-staining assay. (C) ABGE induced a statistically significant increase of apoptosis in SGC-7901 cells. Results are represented as the mean \pm SD from three independent experiments. The data were analyzed using the Student's t-test. "Significant difference from negative control $(\mathrm{p}<0.05)$. ABGE, aged black garlic extract; NC, negative control.

$\mathbf{A}$

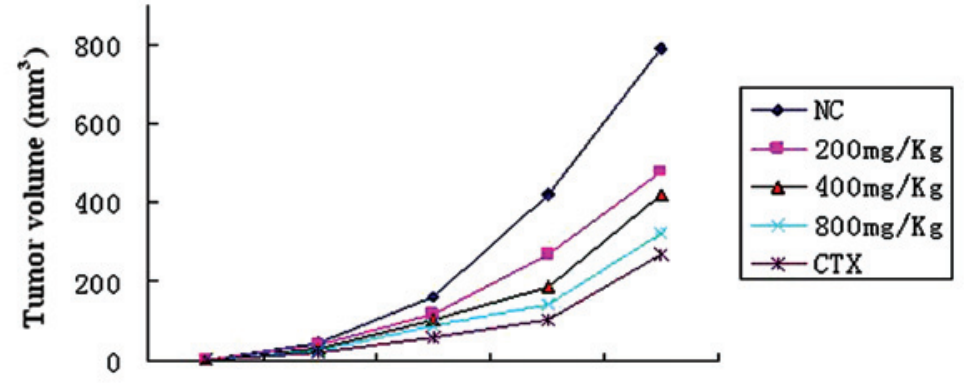

B

Day $1 \quad$ Day $4 \quad$ Day $7 \quad$ Day 11 Day 14

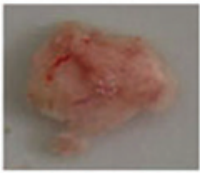

NC

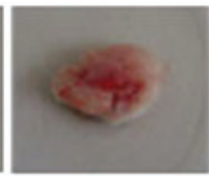

$200 \mathrm{mg} / \mathrm{Kg}$

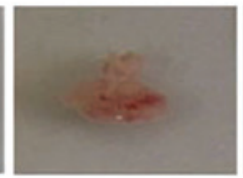

$400 \mathrm{mg} / \mathrm{Kg}$

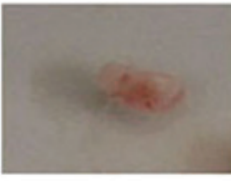

$800 \mathrm{mg} / \mathrm{Kg}$

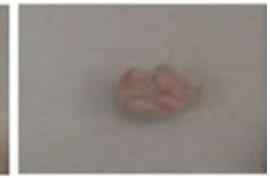

CTX

C

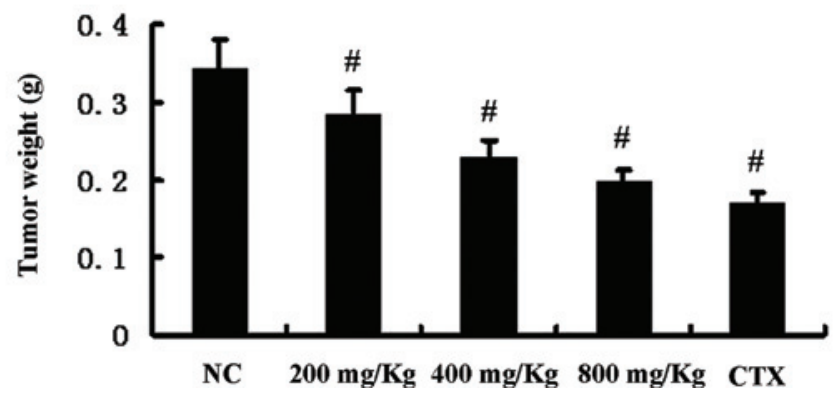

Figure 2. Anti-tumor effects of ABGE in vivo. (A) Comparison of tumor volume between tumor-bearing ABGE-treated mice and negative control. The tumor volumes in different groups were measured on days 1, 4, 7, 11 and 14. The tumor volumes were calculated as described in Materials and methods. (B) Gross observation of tumor in MFC-inoculating mice. Representative tumors from each group are shown. (C) Average tumor weight of sacrificed animals at day 14 . Results are represented as the mean \pm SD. All data were compared with the negative control and were analyzed using the Student's t-test. "Significant differences from the negative control $(\mathrm{p}<0.01)$. ABGE, aged black garlic extract; $\mathrm{NC}$, negative control; CTX, group treated with cyclophosphamide as a positive control. 
Table I. Effects of ABGE on tumor growth and index of spleen and thymus in tumor-bearing mice.

\begin{tabular}{lccccc}
\hline Group (n=12) & $\begin{array}{c}\text { Body weight } \\
(\mathrm{g})\end{array}$ & $\begin{array}{c}\text { Tumor weight } \\
(\mathrm{g})\end{array}$ & $\begin{array}{c}\text { Inhibitory rate } \\
(\mathrm{IR}, \%)\end{array}$ & $\begin{array}{c}\text { Spleen index } \\
(\mathrm{mg} / \mathrm{g})\end{array}$ & $\begin{array}{c}\text { Thymus index } \\
(\mathrm{mg} / \mathrm{g})\end{array}$ \\
\hline Negative control & $22.87 \pm 0.98$ & $0.342 \pm 0.0373$ & - & $63.85 \pm 9.68$ & $28.55 \pm 5.75$ \\
ABGE $(200 \mathrm{mg} / \mathrm{kg})$ & $22.15 \pm 1.78$ & $0.284 \pm 0.031^{\mathrm{b}}$ & 17.0 & $81.37 \pm 14.65^{\mathrm{b}}$ & $37.15 \pm 6.02^{\mathrm{b}}$ \\
ABGE $(400 \mathrm{mg} / \mathrm{kg})$ & $23.02 \pm 1.37$ & $0.228 \pm 0.023^{\mathrm{b}}$ & 33.3 & $88.32 \pm 18.41^{\mathrm{b}}$ & $41.38 \pm 5.63^{\mathrm{b}}$ \\
ABGE $(800 \mathrm{mg} / \mathrm{kg})$ & $22.38 \pm 1.65$ & $0.198 \pm 0.016^{\mathrm{b}}$ & 42.1 & $96.13 \pm 16.83^{\mathrm{b}}$ & $43.55 \pm 7.38^{\mathrm{b}}$ \\
CTX & $19.35 \pm 1.14^{\mathrm{b}}$ & $0.169 \pm 0.0139^{\mathrm{b}}$ & 50.6 & $48.94 \pm 13.78^{\mathrm{a}}$ & $18.13 \pm 6.67^{\mathrm{b}}$
\end{tabular}

The inhibitory rate of tumor and the index of spleen and thymus were calculated as described in Materials and methods. All values are presented as mean \pm SD of 12 mice in relevant groups. ${ }^{\mathrm{a}} \mathrm{p}<0.05$; ${ }^{\mathrm{b}} \mathrm{p}<0.01$ vs. negative control; CTX, cyclophosphamide positive control.

well and mixed, from which absorption was then detected at $450 \mathrm{~nm}$. The levels of IL-2 were determined according to the standard curve of absorption-concentration.

Statistical Analysis. All values were expressed as mean \pm standard deviation (SD). Differences were evaluated using the Statistical Package for Social Science 13.0. Statistical analysis was performed using two-sided Student's t-test. Differences were considered statistically significant at $\mathrm{p}<0.05$.

\section{Results}

Effect of ABGE on the apoptosis of SGC-7901 cells. First, SGC-7901 cells were used as an in vitro model to evaluate their apoptotic status following treatment with three dosages of ABGE. It was observed that the morphology of ABGEtreated cells changed from a more elongated fibroblast-like morphology to a round, smaller and packed appearance of epithelial cells $24 \mathrm{~h}$ after exposure to ABGE, indicating that SGC-7901 cells began to exhibit morphological features of apoptosis (Fig. 1A). Flow cytometry (FCM) was performed to further confirm the effects of ABGE on the induction of apoptosis. FCM with PI staining revealed that the apoptosis rates of SGC-7901 cell line treated with 10,50 or $100 \mathrm{mg} / \mathrm{ml} \mathrm{ABGE}$ for $48 \mathrm{~h}$ were $10.9 \pm 3.9 \%, 16.7 \pm 4.8 \%$ and $22.7 \pm 5.8 \%$, respectively, and were significantly higher than that in the negative control (Fig. 1B and C). The results of FCM indicated that the effect of ABGE on apoptosis of SGC-7901 cells occurred in a dose-dependent manner.

Effect of $A B G E$ on inoculated tumors in mice. To determine whether ABGE inhibits tumor growth in vivo, an equal number of MFC cells $\left(8 \times 10^{5}\right)$ were injected into the right axilla of Kunming mice to produce a tumor-bearing model. During the experiment, we measured the tumor volumes of different groups at 1, 4, 7, 11 and 14 days, respectively. As shown in Fig. 2A, the tumor volumes from low, medium and high doses of ABGEtreated tumor-bearing mice were significantly reduced. On the final day (day 14), the mice were sacrificed. Tissues of spleen, thymus and tumor were then removed and weighed. As shown in Fig. 2B and $\mathrm{C}$ the tumor weights of tumor-bearing mice in the ABGE-treated and positive groups markedly decreased compared with the negative control $(\mathrm{p}<0.01)$. According to the afore-mentioned formula, the inhibitory rates of tumor growth in the 3 ABGE groups and the positive control were 17.0, 33.3, 42.1 and $50.6 \%$, respectively. Similarly, the index of spleen (or thymus) gradually increased with the increased dosage of ABGE (Table I). Moreover, it should be noted that no toxicity judged by parallel monitoring of body weight was observed in ABGE-treated mice (Table I). These results indicate that the tumor growth rate was notably inhibited in mice following treatment with ABGE as indicated by monitoring of the proliferation of spleen (or thymus).

Activity of serum SOD and GSH-Px in tumor-bearing mice. To further understand the molecular mechanisms of action of ABGE against the MFC cell growth, we investigated the effects of ABGE on activities of antioxidant enzymes in tumor-bearing mice. Fig. 3A and B show the effect of ABGE on activities of SOD and GSH-Px in the serum. The analysis indicated that, compared with the negative control, ABGE significantly increased the activity of SOD and GSH-Px in a dose-dependent manner $(\mathrm{p}<0.01)$.

Treatment of ABGE increased concentration of serum $I L-2$ in tumor-bearing mice. To determine whether treatment of ABGE has an immunomodulative action, concentrations of serum IL-2 in MFC-bearing mice were assessed. As shown in Fig. 3C, ELISA analysis indicated that, compared with the negative control, the activity of IL-2 increased slightly with the low-dosage ABGE treatment ( $p>0.05$ ). In contrast, significant increase of IL-2 was observed in the medium- and high-dosage groups compared with negative control group $(\mathrm{p}<0.01)$.

\section{Discussion}

Gastric cancer is one of the most common human malignant tumors. Epidemiological investigations have provided evidence that gastric carcinogenesis is a complex, multistep and multifactorial event (15). Considering that reactive oxygen species (ROS) are capable of changing a number of cellular events involved in the cancer process by which cancer cells escape the immune system, the status of oxidative stress and immunity response may be a crucial factor in the development of gastric cancer. Despite continuous progress in the development of conventional therapies such as surgery, chemotherapy, and radiotherapy, as well as novel target-protein-based cancer therapy, gastric cancer is still the second highest cause of 
A

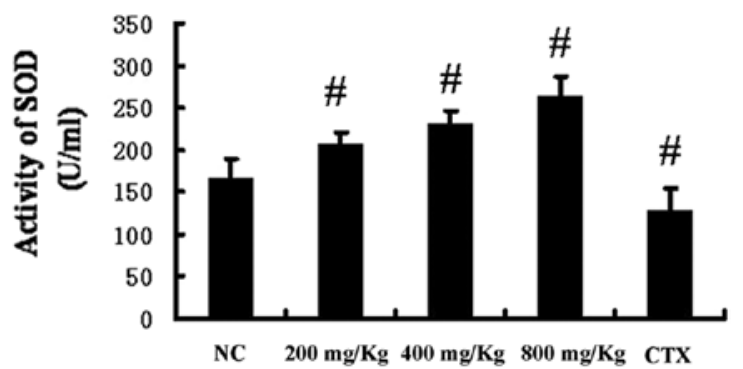

B

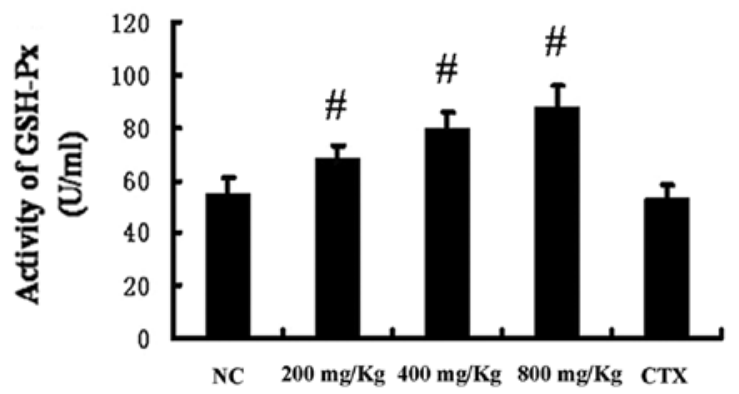

C

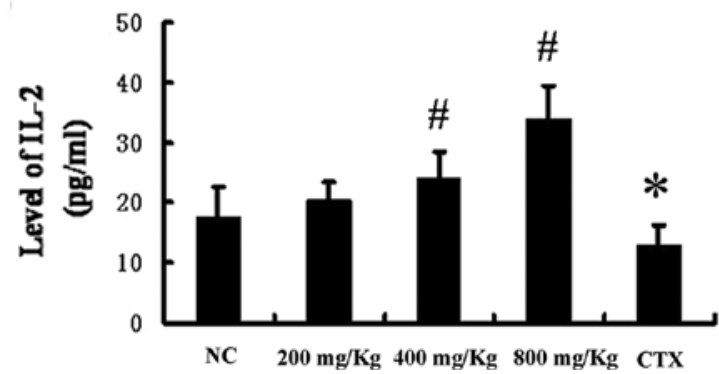

Figure 3. Levels of SOD, GSH-Px and IL-2 in serum of MFC-inoculating mice. (A) Activities of serum SOD in tumor-bearing mice. (B) Activities of serum GSH-Px in tumor-bearing mice. (C) Concentrations of serum IL-2 in tumor-bearing mice. Values are presented as mean \pm SD of 12 mice in relevant groups. Data were compared with the negative control and were analyzed using the Student's t-test. Significant differences from the negative control are indicated by ${ }^{*} \mathrm{p}<0.05$ or ${ }^{\#} \mathrm{p}<0.01$. NC, negative control; CTX, group treated with cyclophosphamide as a positive control.

cancer-related mortality, indicating that the value of these therapies in the management of tumors may have reached a plateau (16). Nutritional support is a recent advancement in the domain of diet-based therapies (17). As a formidable prophylactic and therapeutic medicinal food, garlic and its extracts are significant components of strategies to prevent and cure various malignancies $(18,19)$. To investigate this potential connection, the antioxidant and immunopotentiating effects of ABGE on gastric cancer were examined in SGC-7901 cells in vitro and in a tumor-bearing mouse model in vivo, respectively.

In the last few years, a number of reports have demonstrated the antiproliferative effects of several compounds derived from garlic. The effects displayed by garlic derivatives include induction of apoptosis, regulation of cell cycle progression and modification of pathways of signal transduction, all of which are cancer-reducing events $(20,21)$. In the present study, the apoptosis of SGC-7901 cells increased significantly in a dose-dependent manner following treatment with ABGE. These data are in agreement with those of previous studies. Organosulfur compounds (OSC), components of garlic extrac- tion, can suppress growth of cancer cells of different anatomical locations and modulate a number of key elements in cellular signal transduction pathways related to the apoptotic process (22). In the tumor-bearing mouse model, administration of ABGE effectively suppressed the development of inoculated tumor cells, indicating that ABGE also plays an anticancer role in vivo. Several early studies focused on the analysis of the effects of treatment with garlic or its components on the tumorigenic capabilities of the inoculated tumor cells in test animals. In these studies, reduced tumor growth and increased survival were also observed $(23,24)$.

Formation of ROS is a normal consequence of essential biochemical processes. Low levels of ROS are harmless and necessary in several processes such as intracellular messaging, immunity and defence against microorganisms. In contrast, growing evidence indicates that ROS may lead to a variety of biological responses, including the induction of apoptosis, cell cycle arrest and formation of DNA mutations, which are associated with the pathogenesis of several diseases, including cancer (25-27). Therefore, the balance between ROS production and antioxidant defenses appears to one of the most significant physiological factors for cell transformation.

There are numerous mechanisms by which cells defend themselves against oxidants, forming a defense system mainly comprising antioxidant enzymes. SODs are generally regarded as the first line of antioxidant enzymes that protect cells against ROS, and may contribute to protection against carcinogenesis or tumor progression (28). Another antioxidant enzyme is GSH-Px, which is also a significant $\mathrm{H}_{2} \mathrm{O}_{2}$-scavenging enzyme (29). Although a number of reports have studied the level of SOD and GSH-Px in humans and animal cancer types, the data are conflicting and controversial $(30,31)$. The plausible explanations for this include: i) the fact that treatment strategies that are effective in one type of cancer may be ineffective in another type, and ii) the differences between the cancerous tissues studied.

ROS are also involved in the pathogenesis of gastric malignancies (32). To date, the correlation between administration of ABGE and its effect on the status of SOD and GSH-Px have yet to be fully investigated. In this study, the activities of SOD and GSH-Px were significantly increased by the administration of ABGE in an animal model. Considering that ROS are inversely correlated to the induction of apoptosis (as mentioned above), these results offer a plausible explanation of the antioxidative and antiproliferative effects of ABGE. In the context of the previous literature, administration of ABGE may exert its antioxidative role directly and indirectly. During the aging process of $\mathrm{ABGE}$, compounds in fresh garlic are converted into stable and water-soluble OSCs such as S-allyl cysteine (SAC) and S-allylmercapto-L-cysteine (SAMC). It has been reported that SAC and SAMC possess high radical scavenging activity, which directly removes ROS $(33,34)$. In addition to this direct effect, ABGE also increases the activity of antioxidant enzymes, so that excessive ROS is indirectly cleared (35). Consistent with our study, enhancement of the circulating levels of SOD and GSH-Px were observed following administration of garlic extract in the circulation of tumor-bearing animals.

In addition to ROS, the host immune system plays another major role in tumorigenesis. A number of studies have shown 
that the mechanism by which cancer cells escape detection by the body's immune system plays a key role in the occurrence and development of malignant tumors (36). As a significant immunomodulator, IL-2 is an immune factor secreted by helper T-lymphocytes that serves as a crucial growth and activation factor for cytotoxic lymphocytes, macrophages, natural killer cells and B lymphocytes (37). To date, studies on the effects of garlic to enhance immunocompetence in cancer cells have focused mainly on bladder cancer, since superficial bladder tumors have been shown to be sensitive to several biological response modulators and to immunomodulators in particular. The results demonstrated that administration of ABGE stimulates proliferation of lymphocytes and macrophage phagocytosis, induces splenic hypertrophy and the infiltration of macrophages and lymphocytes, and stimulates release of IL-2 in transplanted tumors (38). It has been reported that the effective dose of $\mathrm{ABGE}$ to enhance immune responses ranged from $1.8 \mathrm{~g} / \mathrm{day}$ to $10 \mathrm{~g} / \mathrm{day}$, indicating that it is more practical for future complementary and alternative therapy (39). In the present study, the level of IL-2 increased gradually in tumor-bearing mice depending on the dosage of ABGE. Moreover, the index of spleen and thymus also increased significantly following administration of ABGE, indicating the existence of hypertrophy of the spleen and thymus and the effective stimulation of the immune response. Recent studies using purified OSCs from garlic have provided a new insight into its immunomodulatory effects. Studies on the effect of diallyl sulfide (DAS) on the serum levels of IL-2 revealed that administration of DAS significantly enhanced serum IL-2 levels in angiogenesisinduced animals compared to untreated control animals (40). In studies of human T cells, SAC was found to inhibit activation of the nuclear protein of the Rel oncogene family (nuclear factor- $\kappa \mathrm{B}$ ). This protein can regulate immune function with the induction of TNF- $\alpha$ or $\mathrm{H}_{2} \mathrm{O}_{2}$ (41). Taking into account that most OSCs in aged garlic are water-soluble, it must be one of the active substances in garlic preparations and account for at least a portion of garlic's immunomodulatory activities.

In summary, the present study indicates that ABGE treatment inhibits growth of SGC-7901 cells by inducing apoptosis in vitro. More importantly, we present the first evidence that ABGE is an effective anticancer garlic preparation in a mouse model. The beneficial effects of ABGE may be partly due to its antioxidative and immunomodulatory activities. Due to its broad range of beneficial effects, serious assessment of ABGE in clinical trials is warranted for the prevention and treatment of gastric cancer.

\section{Acknowledgements}

This study was partly supported by grants from the National Special Foundation of the Ministry of Health of China (No. W2009BX042), the Foundation of Military Scientific and Technological Foundation (No.06G034), the National Natural Science Foundation of China (No. 31000564), the Foundation of Shandong Educational Committee (No. J10LF12 and No. G08LG53).

\section{References}

1. Correa P: Is gastric cancer preventable? Gut 53: 1217-1219, 2004.
2. Pourfarzi F, Whelan A, Kaldor J, et al: The role of diet and other environmental factors in the causation of gastric cancer in Iran-a population based study. Int J Cancer 125: 1953-1960, 2009.

3. Rugge M: Secondary prevention of gastric cancer. Gut 56: $1646-1647,2007$.

4. Kyo E, Uda N, Kasuga S, et al. Immunomodulatory effects of aged garlic extract. J Nutr 131: S1075-S1079, 2001.

5. Thomson M and Ali M: Garlic (Allium sativum): a review of its potential use as an anti-cancer agent. Curr Cancer Drug Targets 3: 67-81, 2003.

6. Milner JA: A historical perspective on garlic and cancer. J Nutr 131: 1027S-1031S, 2001

7. Amagase $\mathrm{H}$, Petesch BL, Matsuura $\mathrm{H}$, et al: Intake of garlic and its bioactive components. J Nutr 131: 955S-962S, 2001.

8. Gardner CD, Lawson LD, Block E, et al: Effect of raw garlic vs. commercial garlic supplements on plasma lipid concentrations in adults with moderate hypercholesterolemia: a randomized clinical trial. Arch Int Med 167: 346-353, 2007.

9. Herman-Antosiewicz A, Powolny AA and Singh SV: Molecular targets of cancer chemoprevention by garlic-derived organosulfides. Acta Pharmacol Sin 28: 1355-1364, 2007.

10. Tu SP, Jiang XH, Lin MC, et al: Suppression of survivin expression inhibits in vivo tumorigenicity and angiogenesis in gastric cancer. Cancer Res 63: 7724-7732, 2003

11. Luo G, Guan X and Zhou L: Apoptotic effect of citrus fruit extract nobiletin on lung cancer cell line A549 in vitro and in vivo. Cancer Biol Ther 7: 966-973, 2008.

12. Monari M, Trinchero A, Calabrese C, et al: Superoxide dismutase in gastric adenocarcinoma: is it a clinical biomarker in the development of cancer? Biomarkers 11: 574-584, 2006.

13. Kaynar H, Meral M, Turhan H, et al: Glutathione peroxidase, glutathione-S-transferase, catalase, xanthine oxidase, $\mathrm{Cu}-\mathrm{Zn}$ superoxide dismutase activities, total glutathione, nitric oxide, and malondialdehyde levels in erythrocytes of patients with small cell and non-small cell lung cancer. Cancer Lett 227: 133-139, 2005.

14. Leyon PV and Kuttan G: Effect of Tinospora cordifolia on the cytokine profile of angiogenesis induced animals. Int Immunopharmacol 4: 1569-1575, 2004.

15. Monari M, Foschi J, Calabrese C, et al: Implications of antioxidant enzymes in human gastric neoplasms. Int J Mol Med 24: 693-700, 2009

16. Plummer M, Vivas J, Lopez G, et al: Chemoprevention of precancerous gastric lesions with antioxidant vitamin supplementation: a randomized trial in a high-risk population. J Natl Cancer Inst 99: 137-146, 2007.

17. Yang CS, Wang X: Green tea and cancer prevention. Nutr Cancer 62: 931-937, 2010.

18. Howard EW, Ling MT, Chua CW, et al: Garlic-derived $\mathrm{S}$-allylmercaptocysteine is a novel in vivo antimetastatic agent for androgen-independent prostate cancer. Clin Cancer Res 13: 1847-1856, 2007.

19. Schaffer EM, Liu JZ, Green J, et al: Garlic and associated allyl sulfur components inhibit N-methyl-N-nitrosourea induced rat mammary carcinogenesis. Cancer Lett 102: 199-204, 1996.

20. Pinto JT and Rivlin RS: Antiproliferative effects of allium derivatives from garlic. J Nutr 131: 1058S-1060S, 2001.

21. Knowles LM and Milner JA: Possible mechanism by which allyl sulfides suppress neoplastic cell proliferation. J Nutr 131: 1061S-1066S, 2001.

22. Amagase $\mathrm{H}$ : Clarifying the real bioactive constituents of garlic. J Nutr 136: 716S-725S, 2006.

23. Riggs DR, DeHaven JI and Lamm DL: Allium sativum (garlic) treatment for murine transitional cell carcinoma. Cancer 79: 1987-1994, 1997.

24. Singh SV: Impact of garlic organosulfides on p21(H-ras) processing. J Nutr 131: 1046S-1048S, 2001.

25. Rigas B and Sun Y: Induction of oxidative stress as a mechanism of action of chemopreventive agents against cancer. Br J Cancer 98: 1157-1160, 2008

26. Minelli A, Bellezza I, Conte C, et al: Oxidative stress-related aging: a role for prostate cancer? Biochim Biophys Acta 1795: 83-91, 2009.

27. Matthews GM, Howarth GS and Butler RN: Nutrient and antioxidant modulation of apoptosis in gastric and colon cancer cells. Cancer Biol Ther 5: 569-572, 2006.

28. Kinnula VL and Crapo JD: Superoxide dismutases in malignant cells and human tumors. Free Radic Biol Med 36: 718-744, 2004. 
29. Zachara BA, Szewczyk-Golec K, Tyloch J, et al: Blood and tissue selenium concentrations and glutathione peroxidase activities in patients with prostate cancer and benign prostate hyperplasia. Neoplasma 52: 248-254, 2005.

30. Yasuda M, Takesue F, Inutsuka S, et al: Prognostic significance of serum superoxide dismutase activity in patients with gastric cancer. Gastric Cancer 5: 148-153, 2002.

31. Czeczot H, Scibior D, Skrzycki M, et al: Glutathione and GSH-dependent enzymes in patients with liver cirrhosis and hepatocellular carcinoma. Acta Biochim Pol 53: 237-242, 2006.

32. Handa O, Naito Y and Yoshikawa T: Helicobacter pylori: a ROS-inducing bacterial species in the stomach. Inflamm Res 59: 997-1003, 2010.

33. Imai J, Ide N, Nagae $\mathrm{S}$, et al: Antioxidant and radical scavenging effects of aged garlic extract and its constituents. Planta Med 60: 417-420, 1994.

34. Borek C: Antioxidant health effects of aged garlic extract. J Nutr 131: 1010S-1015S, 2001.

35. Chen HW, Tsai CW, Yang JJ, et al: The combined effects of garlic oil and fish oil on the hepatic antioxidant and drug-metabolizing enzymes of rats. Br J Nutr 89: 189-200, 2003.
36. Kim R, Emi M and Tanabe K: Cancer immunosuppression and autoimmune disease: beyond immunosuppressive networks for tumour immunity. Immunology 119: 254-264, 2006.

37. Li D, Ronson B, Guo M, et al: Interleukin 2 gene transfer prevents NKG2D suppression and enhances antitumor efficacy in combination with cisplatin for head and neck squamous cell cancer. Cancer Res 62: 4023-4028, 2002.

38. Lamm DL and Riggs DR: Enhanced immunocompetence by garlic: role in bladder cancer and other malignancies. J Nutr 131: 1067S-1070S, 2001.

39. Ishikawa H, Saeki T, Otani T, et al: Aged garlic extract prevents a decline of NK cell number and activity in patients with advanced cancer. J Nutr 136: 816S-820S, 2006.

40. Thejass P and Kuttan G: Antiangiogenic activity of Diallyl Sulfide (DAS). Int Immunopharmacol 7: 295-305, 2007.

41. Liu CT, Su HM, Lii CK, et al: Effect of supplementation with garlic oil on activity of Th1 and Th2 lymphocytes from rats. Planta Med 75: 205-210, 2009. 